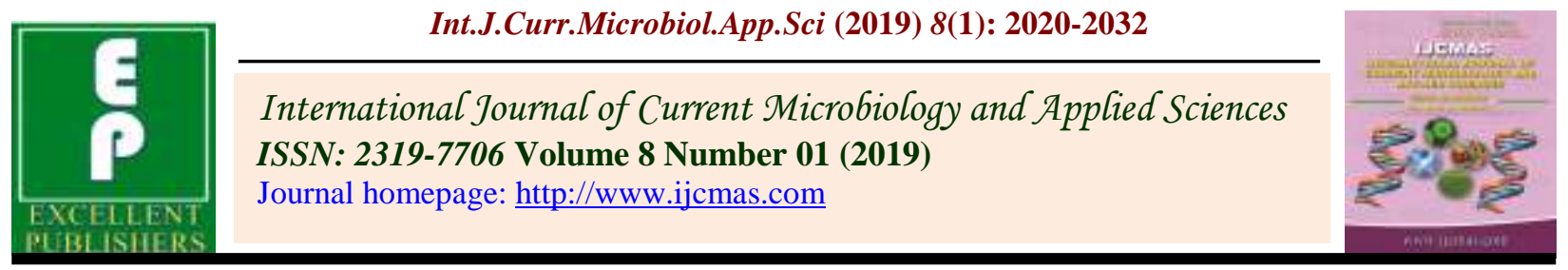

Original Research Article

https://doi.org/10.20546/ijcmas.2019.801.212

\title{
Influence of Date of Sowing and Foliar Application of Nutrients on Crop Growth and Seed Yield of Soybean
}

\author{
G.M. Sumalatha and D.S. Uppar* \\ Department of Seed Science and Technology, College of Agriculture, Dharwad, \\ University of Agricultural Sciences, Dharwad, India \\ *Corresponding author
}

\begin{abstract}
A B S T R A C T
\end{abstract}

\begin{tabular}{|l|}
\hline Key w o r d s \\
Soybean, Date of \\
sowing, Nutrient \\
spray, Crop growth, \\
Seed yield
\end{tabular}

In order to investigate the effect of planting date and foliar application of nutrients on crop growth and seed yield of soybean variety DSb 21. A field experiment was conducted by adopting split plot design with three replications at Main Agricultural Research Station, UAS, Dharwad during kharif, 2016 and 2017. The experiment consisted of three planting dates with fortnight interval (first fortnight of June, second fortnight of June and first fortnight of July) and foliar spray of eight treatments. Among the dates of sowing, first fortnight of June $\left(D_{1}\right)$ recorded significantly highest values for plant height $(65.54 \mathrm{~cm})$, number of branches (12.42), leaf area $\left(56.28 \mathrm{~cm}^{2}\right)$, leaf area index (4.84), chlorophyll content (42.51) and seed yield per hectare (32.35 q). Foliar spray of $\mathrm{KNO}_{3} @ 0.5 \%+$ $\mathrm{KH}_{2} \mathrm{PO} 4 @ 0.5 \%+$ Boron $0.50 \%\left(\mathrm{~T}_{8}\right)$ recorded highest plant height $(64.28 \mathrm{~cm})$, number of branches (10.22), leaf area $\left(54.47 \mathrm{~cm}^{2}\right)$, leaf area index (4.57), chlorophyll content (43.34) and seed yield per hectare $(31.41 \mathrm{q})$. In general, the results of this study indicated that planting date of first fortnight of June sprayed with $\mathrm{KNO}_{3} @ 0.5 \%+\mathrm{KH}_{2} \mathrm{PO}_{4} @ 0.5 \%+$ Boron $0.50 \%$ were suitable for soybean planting in Dharwad region of Karnataka.

\section{Introduction}

Soybean [Glycine max (L.) Merrill] crop is native of China and distributed to Asia, USA, Brazil, Argentina etc. It is synonymously called as 'Chinese pea' or 'Manchurian bean' or "Golden bean" and it is emerged as a miracle crop of $20^{\text {th }}$ century because it is versatile and fascinating crop. Apart from high yielding potential (30-35 q/ha), soybean is very rich in protein $(40 \%)$ and edible oil (20\%) contains a fairly high amount of unsaturated fatty acids and about 1.5 to 3.1 per cent lecithin which is essential for building up of nerve tissue. Soybean is the single largest oilseed produced in the world. It alone contributes about 58 per cent of the global oil seed production. It ranks first in oil seed production followed by rapeseed (13\%), groundnut $(8 \%)$ and sunflower $(7 \%)$. Globally, soybean occupies an area of $126.6 \mathrm{~m}$ ha producing $346.3 \mathrm{mt}$ with the productivity of $2735 \mathrm{~kg}$ per ha. In India soybean occupies an area of $10.60 \mathrm{~m}$ ha producing $12.22 \mathrm{~m} . \mathrm{t}$ with productivity of $1153 \mathrm{~kg}$ per ha and Karnataka with an area of $0.27 \mathrm{~m}$ ha producing $0.17 \mathrm{mt}$ 
with productivity of $639 \mathrm{~kg}$ per ha (Anon., 2017). Climatic factors like temperature, precipitation or rain, snow fall, wind, wind storms, flooding etc., have crucial role in agricultural production.

In agriculture both temperature and precipitation are the dominant climatic factors to affect crop yields which vary widely throughout the year and place (Alexandrov and Hoogenboom, 2001). Planting prior to or later than the optimal planting date can greatly reduce soybean yield and quality since photo periodism controls not only the number of days to flowering, but also the amount of time available for vegetative plant growth and development. Soybeans planted prior or late to optimum range often lose yield from poor emergence due to inadequate soil temperature or, when planted after the optimal range, from failure to fully develop (Bastidas et al., 2008).

To increase the productivity of soybean, it is necessary to provide adequate nutrition to the plant for growth and development. Plant nutrition plays an important role for enhancing seed yield and quality in soybean. Foliar application of nutrients was more beneficial than soil application, since application rates are lesser as compared to soil application, same results were obtained and the crop reacts to nutrient application immediately (Zayed et al., 2011).

Recently, new generation fertilizers have been introduced exclusively for foliar feeding and fertilization. These fertilizers are better source for foliar application (Vibhute, 1998). These fertilizers have different ratios of $\mathrm{N}, \mathrm{P}$ and $\mathrm{K}$ which are highly water soluble and so amenable for foliar nutrition (Jayabal et al., 1999). Quality seed production in soybean is holistic approach which involves the activities like standardization of appropriate season, time of planting and other several techniques to enhance the storability. Keeping all these aspects in view, the present investigation was undertaken.

\section{Materials and Methods}

A Field experiment was conducted during kharif season of 2016 and 2017 at Main Agricultural Research Station, University of Agricultural Sciences, Dharwad. The factors of the experiment was laid out in split plot design and comprised of three date of sowing $\left(D_{1}: 1^{\text {st }}\right.$ fortnight of June, $D_{2}: 2^{\text {nd }}$ fortnight of June and $\mathrm{D}_{3}: 1^{\text {st }}$ fortnight of July) as main plots and foliar spray were considered as subplot $\left(\mathrm{T}_{1}\right.$ : Water spray, $\mathrm{T}_{2}$ : Urea spray @ $2 \%$, $\mathrm{T}_{3}$ : Diammonium phosphate (DAP) @ $2 \%$, $\mathrm{T}_{4}$ : Potassium phosphate $\left(\mathrm{KH}_{2} \mathrm{PO}_{4}\right) @ 1 \%$, $\mathrm{T}_{5}$ : Boron@ 0.50\%, $\mathrm{T}_{6}:$ 19:19:19@3\%+ Boron@0.50\%, T7: $\mathrm{KNO}_{3} @ 1 \%+\mathrm{KH}_{2} \mathrm{PO}_{4}$ @ $0.5 \%$ and $\mathrm{T}_{8}: \mathrm{KNO}_{3} @ 0.5 \%+\mathrm{KH}_{2} \mathrm{PO}_{4} @$ $0.5 \%+$ Boron $0.50 \%$ ) sprayed at 45 days after sowing for soybean $c v$ DSb 21. Crop management factors like land preparation, fertilizer, and weed control were followed as recommended for local area. All the plant protection measures were adopted to make the crop free from insects. The data were recorded on five randomly selected plants of each replication for plant height, number of branches, leaf area, chlorophyll content and seed yield was also recorded. The fortnight meteorological observations during crop growth period are presented in Figure 1.

\section{Results and Discussion}

The plant height and number of branches at 30, 60 days after sowing and at harvest as influenced by date of sowing and foliar application of nutrients and their interaction effects during 2016, 2017 and pooled data are presented in Table 1.

The plant height differed significantly due to different date of sowing. Significantly maximum plant height was recorded in the $D_{1}$ 
(26.40, 24.17 and $25.28 \mathrm{~cm}$ ) followed by $\mathrm{D}_{2}$ (Second fortnight of June: 23.19, 22.16 and $22.68 \mathrm{~cm})$. The lowest plant height $(21.15$, 19.85 and $20.50 \mathrm{~cm}$ ) was recorded in $\mathrm{D}_{3}$ (First fortnight of July) during 2016, 2017 and pooled data respectively at 30 DAS. Significantly higher plant height (65.95, 65.14 and $65.54 \mathrm{~cm}$ ) was recorded in $\mathrm{D}_{1}$ (First fortnight of June) followed by $\mathrm{D}_{2}$ (Second fortnight of June: $63.57,61.37$ and $62.47 \mathrm{~cm}$ ), while lower plant height $(59.43,57.77$ and $58.60 \mathrm{~cm}$ ) was recorded in $\mathrm{D}_{3}$ (First fortnight of July) during 2016, 2017 and pooled data respectively at 60 DAS. Significantly higher plant height $(87.48,85.39$ and $86.44 \mathrm{~cm})$ was recorded in $\mathrm{D}_{1}$ (First fortnight of June) followed by $\mathrm{D}_{2}$ (Second fortnight of June: $83.80,80.51$ and $82.16 \mathrm{~cm}$, while lower plant height $(79.61,76.70$ and $78.15 \mathrm{~cm}$ ) was recorded in $\mathrm{D}_{3}$ (First fortnight of July) during 2016, 2017 and pooled data respectively at harvest.

The number of branches per plant differed significantly due to different date of sowing. Significantly more number of branches (7.53. 6.45 and 6.99) was recorded in $\mathrm{D}_{1}$ (First fortnight of June) followed by $\mathrm{D}_{2}$ (Second fortnight of June: 7.33, 6.12 and 6.73) and lower number of branches per plant (7.01, 5.85 and 6.43) was recorded in $\mathrm{D}_{3}$ (First fortnight of July) during 2016, 2017 and pooled data respectively at 30 Days after Sowing. Significantly higher number of branches per plant (10.65, 10.20 and 10.42) was recorded in $\mathrm{D}_{1}$ (First fortnight of June) followed by $\mathrm{D}_{2}$ (Second fortnight of June: 9.91, 9.74 and 9.83), while lower number of branches per plant $(9.55,9.09$ and 9.32) was recorded in $\mathrm{D}_{3}$ (First fortnight of July) during 2016, 2017 and pooled data respectively at 60 DAS. Significantly higher number of branches per plant (12.60, 12.24 and 12.42) was recorded in $D_{1}$ (First fortnight of June) followed by $\mathrm{D}_{2}$ (Second fortnight of June: 2.26, 12.05 and 12.15), while lower number of branches per plant (11.93, 11.66 and 11.79) was recorded in $\mathrm{D}_{3}$ (First fortnight of July) during 2016, 2017 and pooled data respectively at harvest. This may be due to the optimum environmental conditions like well distribution of rainfall and optimum mean temperature $\left(25.5{ }^{\circ} \mathrm{C}\right)$ and relative humidity (79\%) prevailing in that period, also early and normal planting dates allow a longer growth period, plants are exposed to suitable temperature regimes during the vegetative and reproductive growth stages for the entire growing period. In contrast, plant growth was negatively affected by late planting date due to the decreased vegetative and reproductive growth duration which has been affected by $\left(27^{\circ} \mathrm{C}\right)$ high temperature (Frimpong, 2004). Banterng et al., (2003) reported that both vegetative and reproductive stage in late planting was decreased, thus plant produces less biomass in delayed sowing, which results in shortened plant height. These results are in conformity with the findings of Mohankumar et al., (2011) and Kumar et al., (2015).

Among the foliar application of nutrients, $\mathrm{T}_{8}$ $\left(\mathrm{KNO}_{3} @ 0.5 \%+\mathrm{KH}_{2} \mathrm{PO}_{4} @ 0.5 \%+\right.$ Boron $0.50 \%)$ noticed significantly higher plant height $(65.16,63.40$ and $64.28 \mathrm{~cm}$ : at 60 DAS, 85.40, 82.87 and $84.13 \mathrm{~cm}$ : at harvest) which is on par $(65.15,63.39$ and $64.27 \mathrm{~cm}$ : at 60 DAS, 85.39, 82.86 and $84.12 \mathrm{~cm}$ : at harvest) with $\mathrm{T}_{6}(19: 19: 19 \mathrm{NPK} @ 3 \%+$ Boron@0.50\%)and $\mathrm{T}_{7}\left(\mathrm{KNO}_{3} @ 1 \%+\right.$ $\left.\mathrm{KH}_{2} \mathrm{PO}_{4} @ 0.5 \%\right)$ The lowest plant height (59.50, 57.43 and $58.47 \mathrm{~cm}$ : at 60 DAS, 80.52, 77.56 and $79.04 \mathrm{~cm}$ : at harvest) was recorded in control during 2016, 2017 and pooled data respectively.

Among the foliar application of nutrients, $\mathrm{T}_{8}$ $\left(\mathrm{KNO}_{3} @ 0.5 \%+\mathrm{KH}_{2} \mathrm{PO}_{4} @ 0.5 \%+\right.$ Boron $0.50 \%)$ noticed significantly higher number of branches per plant (10.41, 10.03 and 10.22: at $60 \mathrm{DAS}, 12.60,12.32$ and 12.46: at harvest) which is on par (10.40, 10.02 and 10.21: at 60 
DAS, 12.59, 12.31 and 12.45: at harvest) with T6 (19:19:19 NPK @3\%+Boron@0.50 $\%)$ and $\mathrm{T}_{7}\left(\mathrm{KNO}_{3} @ 1 \%+\mathrm{KH}_{2} \mathrm{PO}_{4} @ 0.5\right.$ $\%$ and lower number of branches per plant (9.47, 9.06 and 9.27 at $60 \mathrm{DAS}, 11.74,11.46$ and 11.60 at harvest) was recorded in control during 2016, 2017 and pooled data respectively at 60 DAS. This treatment composed of $\mathrm{N}, \mathrm{P}, \mathrm{K}$ and high boron plays role in various physiological and biochemical processes contributing to the growth of the meristematic regions. $\mathrm{KH}_{2} \mathrm{PO}_{4}$ induced growth was found to be associated with enhanced higher solute content, water use efficiency, relative water content and photosystem. The above results are in conformity with the observations of Mahmoud et al., (2006) in fababean, Ali and Adel (2013) in mungbean. Beg et al., (2013) reported that, nitrogen being an active participant of chlorophyll molecule and protein is an essential element for plant growth. Spray with potassium salts increased leaf potassium content which helps to maintain osmosis across the cells and tissues of leaves, thereby maintaining higher relative water content at higher rates, photosystem. Hence, there was considerable improvement in growth even under saline strata in present investigation.

Combined application of 19:19:19 NPK @ 3 $\%$ along with Boron @ $0.50 \%)\left(\mathrm{T}_{6}\right)$ also recorded highest plant height and branches compared to control. This might be due to six per cent more $\mathrm{N}$ in 19:19:19 NPK fertilizer compared to $\mathrm{KNO}_{3}$, which might have enhanced plant height, because of its role in cell division and cell elongation at higher levels of nitrogen. This was due to the presence of phosphorus in 19:19:19 NPK fertilizer which helps in cell division and cell development leading to higher number of branches. Results obtained in the present investigation are in accordance with the findings of Prabhavathi et al., (2009) in mungbean.
The leaf area and leaf area index at 30 and 60 days after sowing (DAS) as influenced by date of sowing and foliar application of nutrients and their interaction effects during 2016, 2017 and pooled data are presented in the Table 2.

The leaf area differed significantly due to different date of sowing. Significantly higher leaf area $\left(36.87,35.62\right.$ and $36.25 \mathrm{~cm}^{2}$ ) was recorded in $\mathrm{D}_{1}$ (First fortnight of June) followed by $\mathrm{D}_{2}$ (Second fortnight of June: $33.25,32.30$ and $32.78 \mathrm{~cm}^{2}$ ) and lowest leaf area $\left(31.57,30.59\right.$ and $31.08 \mathrm{~cm}^{2}$ ) was recorded in $\mathrm{D}_{3}$ (First fortnight of July) at 30 DAS. Significantly highest $(56.27,56.28$ and $56.28 \mathrm{~cm}^{2}$ ) leaf area was recorded in $\mathrm{D}_{1}$ (First fortnight of June) followed by $\mathrm{D}_{2}$ (Second fortnight of June: $54.80,53.75$ and $54.28 \mathrm{~cm}^{2}$ ) while lowest leaf area (50.15, 49.99 and 50.07 $\mathrm{cm}^{2}$ ) was recorded in $\mathrm{D}_{3}$ (First fortnight of July) at 60 DAS during 2016, 2017 and pooled data respectively.

The leaf area index differed significantly due to different date of sowing. Significantly higher leaf area index (2.61, 2.43 and 2.52) was recorded in $\mathrm{D}_{1}$ (First fortnight of June) followed by $\mathrm{D}_{2}$ (Second fortnight of June: 2.17, 1.91 and 2.04) and lowest leaf area index (1.78, 1.67 and 1.72) was recorded in $\mathrm{D}_{3}$ (First fortnight of July) at 30 DAS. The leaf area index differed significantly due to different date of sowing. Significantly highest leaf area index $\left(4.90,4.78\right.$ and 4.87) was recorded in $\mathrm{D}_{1}$ (First fortnight of June) followed by $\mathrm{D}_{2}$ (Second fortnight of June: 4.57, 4.33 and 4.45) while lowest leaf area index $(3.83,3.77$ and 3.80) was recorded in $D_{3}$ (First fortnight of July) at 60 DAS during 2016, 2017 and pooled data respectively.

Among the foliar application of nutrients, $\mathrm{T}_{8}$ $\left(\mathrm{KNO}_{3} @ 0.5 \%+\mathrm{KH}_{2} \mathrm{PO}_{4} @ 0.5 \%+\right.$ Boron $0.50 \%$ ) noticed significantly highest leaf area (54.71, 54.22 and $54.47 \mathrm{~cm}^{2}$ ) and leaf area index $(4.64,4.50$ and 4.57) which is on par 
leaf area $\left(54.71,54.21\right.$ and $\left.54.46 \mathrm{~cm}^{2}\right)$ and leaf area index $\left(4.64,4.49\right.$ and 4.57) with $\mathrm{T}_{6}$ (19:19:19 NPK@3\%+Boron@0.50\%) and $\mathrm{T}_{7}\left(\mathrm{KNO}_{3} @ 1 \%+\mathrm{KH}_{2} \mathrm{PO}_{4} @ 0.5 \%\right)$ and lowest leaf area $\left(52.26,51.92\right.$ and $\left.52.09 \mathrm{~cm}^{2}\right)$ and leaf area index $(4.08,3.93$ and 4.01) was recorded in control during 2016, 2017 and pooled data respectively at 60 DAS. This might be due to maintenance of higher leaf area, leaf dry matter and crop growth rate by utilizing the foliar applied nutrients. These results are in line with the findings of Pradeep and Elamathi (2007) and Zayed et al., (2011). T 6 (19:19:19 NPK @ 3\%+Boron@0.50\%) also recorded significantly higher value of leaf area, this might be due to nitrogen being chief constituent of protein and protoplasm has enhanced the synthesis of chlorophyll content of the leaves and cell division thus resulted in more no of leaves attributed towards more leaf area. These results are in confirmation with the findings of Sarkar and Pal (2006) and Gupta et al., (2011) (Table 3).

The SPAD reading at full bloom stage differed significantly due to different date of sowing. Significantly higher SPAD reading (43.19, 41.82 and 42.51) was recorded in $\mathrm{D}_{1}$ (First fortnight of June) followed by $\mathrm{D}_{2}$ (Second date of sowing: 40.80, 38.65 and 39.73) and lowest SPAD reading (39.83, 37.93 and 38.88) was recorded in $\mathrm{D}_{3}$ (First fortnight of July) during 2016, 2017 and pooled data respectively. Delayed sowing reduces SPAD meter readings, which might be due to drought stress reduced the total chlorophyll and per cent of seed storage protein. This is in line with the findings of Patel and Hemantaranjan (2013), they reported that increasing in the level of total phenolics content were observed under drought stress and thus reduced the total chlorophyll content. Singla et al., (2016) revealed higher photosynthetic rate (Ps), transpiration rate (Tr), leaf area index (LAI), and SPAD values were observed in mid-June sowing than early-July and late-July sowing.
Gowthami et al., (2018) stated that, higher total chlorophyll content due to foliar spray of potassium nitrate $(2 \%)+$ Boric acid $(0.5 \%)+$ zinc sulphate $(1 \%)$ at 30 and 60 DAS treatment might be due to increase in the photosynthetic pigments like chlorophylls and carotenoids by foliar application of boron and increase in the rate of photosynthesis. These results are in conformity with the findings of Thurzo et al., (2010) in sweet cherry.

Among the different dates of sowing, $\mathrm{D}_{1}$ (June first fortnight) significantly taken more number of days for beginning bloom (39.37, 38.60 and 38.99 days), full bloom (49.07, 48.08 and 48.57 days), beginning pod (46.93, 46.09 and 46.51 days), full pod (64.48, 63.94 and 64.21 days), beginning seed (57.02, 55.92 and 56.47 days), full seed (75.68, 74.30 and 74.99 days), beginning maturity $(74.69,71.49$ and 73.09 days) and full maturity (98.15, 97.37 and 97.76 days) followed by $D_{2}$ beginning bloom $(36.18,36.17$ and 36.17 days), full bloom (45.60, 46.16 and 45.88 days), beginning pod (44.41, 44.32 and 44.36 days), full pod (61.67, 61.71 and 61.69 days), beginning seed $(54.15,53.345$ and 53.75 days), full seed (72.68, 72.39 and 72.54 days), beginning maturity $(71.49,72.26$ and 71.87 days) and full maturity (95.25, 96.10 and 95.68 days). Significantly less number of days for beginning bloom (34.93, 33.93 and 34.43 days), full bloom (45.06, 44.06 and 44.56 days), beginning pod (44.05, 43.91 and 43.98 days), full pod (60.70, 59.70 and 60.20 days), beginning seed (51.83, 50.83 and 51.33 days), full seed (69.68, 68.68 and 69.18 days), beginning maturity $(68.91,74.69$ and 71.80 days) and full maturity (94.66, 93.66 and 94.16 days) was recorded under $\mathrm{D}_{3}$ (Third date of sowing) during 2016, 2017 and pooled data, respectively as presented in Figure 2. This might be due to more difference in maximum and minimum temperature $\left(6.09\right.$ and $\left.6.92{ }^{\circ} \mathrm{C}\right)$ during second fortnight of June and first fortnight of July, respectively). 
Table.1 Effect of date of sowing and foliar application of nutrients on plant height and number of branches at different growth stages of soybean

\begin{tabular}{|c|c|c|c|c|c|c|c|c|c|c|c|c|c|c|c|c|c|c|}
\hline \multirow{3}{*}{ Treatments } & \multicolumn{9}{|c|}{ Plant height (cm) } & \multicolumn{9}{|c|}{ Number of branches } \\
\hline & \multicolumn{3}{|c|}{30 DAS } & \multicolumn{3}{|c|}{60 DAS } & \multicolumn{3}{|c|}{ At harvest } & \multicolumn{3}{|c|}{30 DAS } & \multicolumn{3}{|c|}{ 60 DAS } & \multicolumn{3}{|c|}{ At harvest } \\
\hline \multirow{2}{*}{\multicolumn{19}{|c|}{ Main plot (D) }} \\
\hline & & & & & & & & & & & & & & & & & & \\
\hline$D_{1}$ & 26.40 & 24.17 & 25.28 & 65.95 & 65.14 & 65.54 & 87.48 & 85.39 & 86.44 & 7.53 & 6.45 & 6.99 & 10.65 & 10.20 & 10.42 & 12.60 & 12.24 & 12.42 \\
\hline $\mathrm{D}_{2}$ & 23.19 & 22.16 & 22.68 & 63.57 & 61.37 & 62.47 & 83.80 & 80.51 & 82.16 & 7.33 & 6.12 & 6.73 & 9.91 & 9.74 & 9.83 & 12.26 & 12.05 & 12.15 \\
\hline$D_{3}$ & 21.15 & 19.85 & 20.50 & 59.43 & 57.77 & 58.60 & 79.61 & 76.70 & 78.15 & 7.01 & 5.85 & 6.43 & 9.55 & 9.09 & 9.32 & 11.93 & 11.66 & 11.79 \\
\hline S. Em. \pm & 0.10 & 0.09 & 0.05 & 0.19 & 0.19 & 0.10 & 0.29 & 0.30 & 0.15 & 0.02 & 0.02 & 0.01 & 0.03 & 0.03 & 0.02 & 0.03 & 0.02 & 0.01 \\
\hline C.D. @ 5\% & 0.41 & 0.36 & 0.16 & 0.76 & 0.75 & 0.31 & 1.14 & 1.18 & 0.48 & 0.08 & 0.09 & 0.03 & 0.13 & 0.12 & 0.05 & 0.10 & 0.08 & 0.04 \\
\hline \multicolumn{19}{|l|}{ Sub Plot (T) } \\
\hline$T_{1}$ & 23.41 & 22.04 & 22.73 & 59.50 & 57.43 & 58.47 & 80.52 & 77.56 & 79.04 & 7.28 & 6.13 & 6.71 & 9.47 & 9.06 & 9.27 & 11.74 & 11.46 & 11.60 \\
\hline$T_{2}$ & 23.44 & 22.06 & 22.75 & 61.46 & 60.69 & 61.07 & 82.43 & 79.81 & 81.12 & 7.29 & 6.14 & 6.72 & 9.83 & 9.48 & 9.66 & 12.08 & 11.76 & 11.92 \\
\hline $\mathbf{T}_{3}$ & 24.66 & 22.06 & 23.36 & 62.82 & 61.39 & 62.11 & 83.80 & 80.75 & 82.27 & 7.29 & 6.14 & 6.71 & 10.00 & 9.70 & 9.85 & 12.22 & 11.93 & 12.08 \\
\hline$T_{4}$ & 23.42 & 22.07 & 22.75 & 64.14 & 62.58 & 63.36 & 84.67 & 81.83 & 83.25 & 7.28 & 6.14 & 6.71 & 10.19 & 9.85 & 10.02 & 12.38 & 12.11 & 12.25 \\
\hline$T_{5}$ & 23.43 & 22.06 & 22.75 & 60.47 & 59.15 & 59.81 & 81.44 & 78.42 & 79.93 & 7.29 & 6.14 & 6.71 & 9.61 & 9.25 & 9.43 & 11.90 & 11.63 & 11.76 \\
\hline$T_{6}$ & 23.43 & 22.06 & 22.75 & 65.15 & 63.39 & 64.27 & 85.39 & 82.86 & 84.12 & 7.29 & 6.14 & 6.71 & 10.40 & 10.02 & 10.21 & 12.59 & 12.31 & 12.45 \\
\hline $\mathbf{T}_{7}$ & 23.43 & 22.07 & 22.75 & 65.15 & 63.39 & 64.27 & 85.39 & 82.86 & 84.12 & 7.28 & 6.14 & 6.71 & 10.40 & 10.02 & 10.21 & 12.59 & 12.31 & 12.45 \\
\hline$T_{8}$ & 23.42 & 22.06 & 22.74 & 65.16 & 63.40 & 64.28 & 85.40 & 82.87 & 84.13 & 7.29 & 6.14 & 6.72 & 10.41 & 10.03 & 10.22 & 12.60 & 12.32 & 12.46 \\
\hline S. Em. \pm & 0.23 & 0.21 & 0.11 & 0.50 & 0.49 & 0.25 & 0.75 & 0.77 & 0.38 & 0.05 & 0.06 & 0.03 & 0.08 & 0.07 & 0.04 & 0.07 & 0.05 & 0.03 \\
\hline C.D. @ 5\% & NS & NS & NS & 1.41 & 1.39 & 0.69 & 2.13 & 2.18 & 1.06 & NS & NS & NS & 0.23 & 0.20 & 0.11 & 0.21 & 0.15 & 0.09 \\
\hline \multicolumn{19}{|l|}{ Interactions $(\mathrm{D} \times \mathrm{T})$} \\
\hline$D_{1} \mathbf{T}_{I}$ & 25.91 & 24.14 & 25.03 & 62.15 & 61.28 & 61.71 & 84.16 & 81.64 & 82.90 & 7.52 & 6.44 & 6.98 & 10.09 & 9.69 & 9.89 & 12.06 & 11.62 & 11.84 \\
\hline $\mathbf{D}_{1} \mathbf{T}_{2}$ & 25.93 & 24.16 & 25.04 & 64.28 & 64.72 & 64.50 & 86.21 & 84.25 & 85.23 & 7.53 & 6.45 & 6.99 & 10.48 & 10.02 & 10.25 & 12.39 & 11.91 & 12.15 \\
\hline$D_{1} T_{3}$ & 29.63 & 24.16 & 26.90 & 65.32 & 65.41 & 65.37 & 87.46 & 85.63 & 86.55 & 7.53 & 6.45 & 6.99 & 10.69 & 10.20 & 10.45 & 12.52 & 12.17 & 12.35 \\
\hline$D_{1} T_{4}$ & 25.94 & 24.17 & 25.06 & 67.56 & 66.28 & 66.92 & 88.65 & 86.34 & 87.50 & 7.53 & 6.45 & 6.99 & 10.81 & 10.32 & 10.57 & 12.68 & 12.38 & 12.53 \\
\hline$D_{1} T_{5}$ & 25.96 & 24.19 & 25.08 & 63.58 & 62.38 & 62.98 & 85.63 & 82.46 & 84.05 & 7.52 & 6.44 & 6.98 & 10.25 & 9.82 & 10.04 & 12.22 & 11.78 & 12.00 \\
\hline $\mathrm{D}_{1} \mathrm{~T}_{6}$ & 25.96 & 24.18 & 25.07 & 68.24 & 67.00 & 67.62 & 89.24 & 87.60 & 88.42 & 7.53 & 6.45 & 6.99 & 10.95 & 10.51 & 10.73 & 12.97 & 12.68 & 12.83 \\
\hline $\mathbf{D}_{1} \mathbf{T}_{7}$ & 25.95 & 24.18 & 25.07 & 68.24 & 67.00 & 67.62 & 89.24 & 87.60 & 88.42 & 7.52 & 6.44 & 6.98 & 10.95 & 10.51 & 10.73 & 12.97 & 12.68 & 12.83 \\
\hline $\mathbf{D}_{1} \mathbf{T}_{8}$ & 25.93 & 24.15 & 25.04 & 68.25 & 67.01 & 67.63 & 89.25 & 87.61 & 88.43 & 7.52 & 6.44 & 6.98 & 10.96 & 10.52 & 10.74 & 12.98 & 12.69 & 12.84 \\
\hline $\mathbf{D}_{2} \mathbf{T}_{1}$ & 23.17 & 22.14 & 22.66 & 60.89 & 56.79 & 58.84 & 80.79 & 77.62 & 79.21 & 7.33 & 6.11 & 6.72 & 9.24 & 9.07 & 9.16 & 11.68 & 11.52 & 11.60 \\
\hline $\mathbf{D}_{2} \mathbf{T}_{2}$ & 23.23 & 22.15 & 22.69 & 62.39 & 60.89 & 61.64 & 82.46 & 79.64 & 81.05 & 7.34 & 6.13 & 6.74 & 9.70 & 9.58 & 9.64 & 12.07 & 11.87 & 11.97 \\
\hline $\mathbf{D}_{2} \mathbf{T}_{3}$ & 23.18 & 22.17 & 22.68 & 63.51 & 61.38 & 62.45 & 83.98 & 80.09 & 82.04 & 7.33 & 6.11 & 6.72 & 9.83 & 9.79 & 9.81 & 12.22 & 12.02 & 12.12 \\
\hline $\mathbf{D}_{2} \mathbf{T}_{4}$ & 23.18 & 22.17 & 22.68 & 64.28 & 62.82 & 63.55 & 84.62 & 81.28 & 82.95 & 7.32 & 6.12 & 6.72 & 10.12 & 9.95 & 10.03 & 12.41 & 12.19 & 12.30 \\
\hline$D_{2} T_{5}$ & 23.17 & 22.15 & 22.66 & 61.46 & 59.27 & 60.37 & 81.63 & 78.46 & 80.05 & 7.32 & 6.12 & 6.72 & 9.39 & 9.28 & 9.34 & 11.86 & 11.73 & 11.80 \\
\hline $\mathbf{D}_{2} \mathbf{T}_{6}$ & 23.20 & 22.16 & 22.68 & 65.33 & 63.27 & 64.30 & 85.63 & 82.33 & 83.98 & 7.32 & 6.12 & 6.72 & 10.33 & 10.08 & 10.21 & 12.60 & 12.34 & 12.47 \\
\hline $\mathbf{D}_{2} \mathbf{T}_{7}$ & 23.20 & 22.18 & 22.69 & 65.33 & 63.27 & 64.30 & 85.63 & 82.33 & 83.98 & 7.32 & 6.12 & 6.72 & 10.33 & 10.08 & 10.21 & 12.60 & 12.34 & 12.47 \\
\hline $\mathbf{D}_{2} \mathbf{T}_{8}$ & 23.21 & 22.16 & 22.69 & 65.34 & 63.28 & 64.31 & 85.64 & 82.34 & 83.99 & 7.34 & 6.13 & 6.74 & 10.34 & 10.09 & 10.22 & 12.61 & 12.35 & 12.48 \\
\hline $\mathbf{D}_{3} \mathbf{T}_{1}$ & 21.16 & 19.83 & 20.50 & 55.47 & 54.22 & 54.85 & 76.62 & 73.41 & 75.02 & 7.00 & 5.84 & 6.42 & 9.08 & 8.42 & 8.75 & 11.48 & 11.25 & 11.37 \\
\hline $\mathbf{D}_{3} \mathbf{T}_{2}$ & 21.15 & 19.86 & 20.51 & 57.69 & 56.46 & 57.08 & 78.61 & 75.53 & 77.07 & 7.00 & 5.84 & 6.42 & 9.31 & 8.85 & 9.08 & 11.78 & 11.50 & 11.64 \\
\hline$D_{3} T_{3}$ & 21.18 & 19.84 & 20.51 & 59.64 & 57.37 & 58.51 & 79.96 & 76.52 & 78.24 & 7.01 & 5.85 & 6.43 & 9.48 & 9.11 & 9.30 & 11.92 & 11.61 & 11.77 \\
\hline $\mathbf{D}_{3} \mathbf{T}_{4}$ & 21.15 & 19.87 & 20.51 & 60.58 & 58.64 & 59.61 & 80.73 & 77.86 & 79.30 & 7.00 & 5.84 & 6.42 & 9.64 & 9.28 & 9.46 & 12.06 & 11.77 & 11.91 \\
\hline$D_{3} T_{5}$ & 21.17 & 19.84 & 20.51 & 56.37 & 55.79 & 56.08 & 77.06 & 74.34 & 75.70 & 7.02 & 5.86 & 6.44 & 9.19 & 8.66 & 8.92 & 11.61 & 11.37 & 11.49 \\
\hline $\mathrm{D}_{3} \mathrm{~T}_{6}$ & 21.14 & 19.85 & 20.50 & 61.88 & 59.90 & 60.89 & 81.30 & 78.64 & 79.97 & 7.01 & 5.85 & 6.43 & 9.90 & 9.47 & 9.69 & 12.19 & 11.91 & 12.05 \\
\hline $\mathbf{D}_{3} \mathbf{T}_{7}$ & 21.13 & 19.85 & 20.49 & 61.88 & 59.90 & 60.89 & 81.30 & 78.64 & 79.97 & 7.01 & 5.85 & 6.43 & 9.90 & 9.47 & 9.69 & 12.19 & 11.91 & 12.05 \\
\hline $\mathbf{D}_{3} \mathbf{T}_{8}$ & 21.13 & 19.86 & 20.50 & 61.89 & 59.91 & 60.90 & 81.31 & 78.65 & 79.98 & 7.02 & 5.86 & 6.44 & 9.91 & 9.48 & 9.70 & 12.20 & 11.92 & 12.06 \\
\hline S. Em. \pm & 0.68 & 0.63 & 0.33 & 1.49 & 1.47 & 0.74 & 2.24 & 2.30 & 1.14 & 0.16 & 0.18 & 0.09 & 0.24 & 0.21 & 0.11 & 0.22 & 0.16 & 0.10 \\
\hline C.D. @ 5\% & NS & NS & NS & NS & NS & NS & NS & NS & NS & NS & NS & NS & NS & NS & NS & NS & NS & NS \\
\hline
\end{tabular}


Table.2 Effect of date of sowing and foliar application of nutrients on leaf area and leaf area index at different growth stages of soybean

\begin{tabular}{|c|c|c|c|c|c|c|c|c|c|c|c|c|}
\hline \multirow{3}{*}{$\begin{array}{l}\text { Treatments } \\
\text { Main plot (D) }\end{array}$} & \multicolumn{6}{|c|}{ Leaf area $\left(\mathrm{cm}^{2}\right)$} & \multicolumn{6}{|c|}{ Leaf area index } \\
\hline & \multicolumn{3}{|c|}{30 DAS } & \multicolumn{3}{|c|}{60 DAS } & \multicolumn{3}{|c|}{30 DAS } & \multicolumn{3}{|c|}{60 DAS } \\
\hline & 2016 & 2017 & Pooled & 2016 & 2017 & Pooled & 2016 & 2017 & Pooled & 2016 & 2017 & Pooled \\
\hline$D_{1}$ & 36.87 & 35.62 & 36.25 & 56.27 & 56.28 & 56.28 & 2.61 & 2.43 & 2.52 & 4.90 & 4.78 & 4.84 \\
\hline $\mathbf{D}_{2}$ & 33.25 & 32.30 & 32.78 & 54.80 & 53.75 & 54.28 & 2.17 & 1.91 & 2.04 & 4.57 & 4.33 & 4.45 \\
\hline $\mathbf{D}_{3}$ & 31.57 & 30.59 & 31.08 & 50.15 & 49.99 & 50.07 & 1.78 & 1.67 & 1.72 & 3.83 & 3.77 & 3.80 \\
\hline S. Em. \pm & 0.13 & 0.13 & 0.07 & 0.19 & 0.19 & 0.09 & 0.01 & 0.02 & 0.01 & 0.02 & 0.02 & 0.01 \\
\hline C.D. @ 5\% & 0.52 & 0.50 & 0.21 & 0.73 & 0.74 & 0.31 & 0.06 & 0.06 & 0.02 & 0.08 & 0.08 & 0.03 \\
\hline \multicolumn{13}{|l|}{ Sub Plot $(T)$} \\
\hline$T_{1}$ & 32.50 & 31.24 & 31.87 & 52.26 & 51.92 & 52.09 & 1.92 & 1.77 & 1.84 & 4.08 & 3.93 & 4.01 \\
\hline $\mathbf{T}_{2}$ & 33.08 & 31.84 & 32.46 & 53.10 & 52.84 & 52.97 & 2.07 & 1.87 & 1.97 & 4.31 & 4.17 & 4.24 \\
\hline$T_{3}$ & 33.92 & 32.68 & 33.30 & 53.51 & 53.31 & 53.41 & 2.20 & 2.00 & 2.10 & 4.39 & 4.29 & 4.34 \\
\hline$T_{4}$ & 33.30 & 31.94 & 32.62 & 54.29 & 53.73 & 54.01 & 2.05 & 1.86 & 1.96 & 4.55 & 4.39 & 4.47 \\
\hline $\mathbf{T}_{5}$ & 34.16 & 32.96 & 33.56 & 52.61 & 52.32 & 52.46 & 2.21 & 1.99 & 2.10 & 4.21 & 4.07 & 4.14 \\
\hline$T_{6}$ & 34.98 & 34.46 & 34.72 & 54.71 & 54.21 & 54.46 & 2.40 & 2.24 & 2.32 & 4.64 & 4.49 & 4.57 \\
\hline $\mathbf{T}_{7}$ & 34.61 & 33.80 & 34.21 & 54.71 & 54.21 & 54.46 & 2.31 & 2.15 & 2.23 & 4.64 & 4.49 & 4.57 \\
\hline $\mathbf{T}_{8}$ & 34.60 & 33.80 & 34.20 & 54.71 & 54.22 & 54.47 & 2.31 & 2.15 & 2.23 & 4.64 & 4.50 & 4.57 \\
\hline S. Em. \pm & 0.41 & 0.39 & 0.20 & 0.30 & 0.31 & 0.09 & 0.04 & 0.04 & 0.02 & 0.05 & 0.05 & 0.02 \\
\hline C.D. @ 5 \% & NS & NS & NS & 0.90 & 0.93 & 0.27 & NS & NS & NS & 0.14 & 0.13 & 0.07 \\
\hline \multicolumn{13}{|c|}{ Interactions (D x T) } \\
\hline $\mathbf{D}_{1} \mathbf{T}_{\mathbf{I}}$ & 35.25 & 33.21 & 34.23 & 54.89 & 55.01 & 54.95 & 2.24 & 2.06 & 2.15 & 4.55 & 4.46 & 4.51 \\
\hline $\mathbf{D}_{1} \mathbf{T}_{2}$ & 36.23 & 34.39 & 35.31 & 55.67 & 55.92 & 55.80 & 2.47 & 2.28 & 2.37 & 4.79 & 4.71 & 4.75 \\
\hline$D_{1} T_{3}$ & 37.20 & 35.53 & 36.37 & 56.02 & 56.17 & 56.10 & 2.65 & 2.42 & 2.53 & 4.87 & 4.78 & 4.83 \\
\hline $\mathbf{D}_{1} \mathbf{T}_{4}$ & 36.35 & 34.62 & 35.49 & 56.85 & 56.68 & 56.77 & 2.44 & 2.28 & 2.36 & 5.04 & 4.87 & 4.96 \\
\hline $\mathbf{D}_{1} \mathbf{T}_{5}$ & 37.21 & 35.82 & 36.52 & 55.01 & 55.38 & 55.20 & 2.65 & 2.42 & 2.53 & 4.67 & 4.59 & 4.63 \\
\hline$D_{1} T_{6}$ & 38.00 & 37.95 & 37.98 & 57.24 & 57.03 & 57.14 & 2.92 & 2.75 & 2.84 & 5.09 & 4.94 & 5.02 \\
\hline $\mathbf{D}_{1} \mathbf{T}_{7}$ & 37.35 & 36.73 & 37.04 & 57.24 & 57.03 & 57.14 & 2.76 & 2.60 & 2.68 & 5.09 & 4.94 & 5.02 \\
\hline $\mathbf{D}_{1} \mathbf{T}_{8}$ & 37.35 & 36.73 & 37.04 & 57.23 & 57.04 & 57.14 & 2.76 & 2.60 & 2.68 & 5.10 & 4.94 & 5.02 \\
\hline $\mathbf{D}_{2} \mathbf{T}_{1}$ & 31.52 & 30.72 & 31.12 & 53.68 & 52.19 & 52.94 & 1.93 & 1.71 & 1.82 & 4.25 & 3.97 & 4.11 \\
\hline $\mathbf{D}_{2} \mathbf{T}_{2}$ & 32.16 & 31.26 & 31.71 & 54.38 & 53.28 & 53.83 & 2.05 & 1.77 & 1.91 & 4.46 & 4.16 & 4.31 \\
\hline $\mathbf{D}_{2} \mathbf{T}_{3}$ & 33.22 & 32.36 & 32.79 & 54.85 & 53.92 & 54.39 & 2.19 & 1.93 & 2.06 & 4.54 & 4.33 & 4.43 \\
\hline $\mathbf{D}_{2} \mathbf{T}_{4}$ & 32.46 & 31.46 & 31.96 & 55.03 & 54.12 & 54.57 & 2.04 & 1.76 & 1.90 & 4.64 & 4.42 & 4.53 \\
\hline $\mathbf{D}_{2} \mathbf{T}_{5}$ & 33.64 & 32.52 & 33.08 & 54.08 & 52.64 & 53.36 & 2.21 & 1.91 & 2.06 & 4.38 & 4.05 & 4.22 \\
\hline$D_{2} T_{6}$ & 34.56 & 33.62 & 34.09 & 55.46 & 54.62 & 55.04 & 2.35 & 2.12 & 2.24 & 4.75 & 4.57 & 4.66 \\
\hline $\mathbf{D}_{2} \mathbf{T}_{7}$ & 34.21 & 33.25 & 33.73 & 55.46 & 54.62 & 55.04 & 2.28 & 2.04 & 2.16 & 4.75 & 4.57 & 4.66 \\
\hline $\mathbf{D}_{2} \mathbf{T}_{8}$ & 34.21 & 33.25 & 33.73 & 55.47 & 54.63 & 55.05 & 2.28 & 2.04 & 2.16 & 4.76 & 4.58 & 4.67 \\
\hline $\mathbf{D}_{3} \mathbf{T}_{1}$ & 30.72 & 29.78 & 30.25 & 48.21 & 48.55 & 48.38 & 1.59 & 1.53 & 1.56 & 3.44 & 3.38 & 3.41 \\
\hline $\mathbf{D}_{3} \mathbf{T}_{2}$ & 30.86 & 29.86 & 30.36 & 49.25 & 49.31 & 49.28 & 1.68 & 1.57 & 1.63 & 3.69 & 3.65 & 3.67 \\
\hline$D_{3} T_{3}$ & 31.34 & 30.16 & 30.75 & 49.67 & 49.83 & 49.75 & 1.77 & 1.64 & 1.71 & 3.77 & 3.76 & 3.77 \\
\hline $\mathbf{D}_{3} \mathbf{T}_{4}$ & 31.10 & 29.73 & 30.42 & 51.00 & 50.38 & 50.69 & 1.68 & 1.54 & 1.61 & 3.96 & 3.88 & 3.92 \\
\hline $\mathbf{D}_{3} \mathbf{T}_{5}$ & 31.63 & 30.53 & 31.08 & 48.73 & 48.93 & 48.83 & 1.78 & 1.64 & 1.71 & 3.59 & 3.58 & 3.58 \\
\hline$D_{3} T_{6}$ & 32.38 & 31.82 & 32.10 & 51.43 & 50.97 & 51.20 & 1.94 & 1.86 & 1.90 & 4.07 & 3.97 & 4.02 \\
\hline $\mathbf{D}_{3} \mathbf{T}_{7}$ & 32.28 & 31.43 & 31.86 & 51.43 & 50.97 & 51.20 & 1.88 & 1.79 & 1.84 & 4.07 & 3.97 & 4.02 \\
\hline $\mathbf{D}_{3} \mathbf{T}_{8}$ & 32.23 & 31.43 & 31.83 & 51.44 & 50.98 & 51.21 & 1.88 & 1.79 & 1.84 & 4.08 & 3.97 & 4.03 \\
\hline S. Em. \pm & 1.22 & 1.17 & 0.60 & 1.42 & 1.43 & 0.71 & 0.11 & 0.12 & 0.06 & 0.14 & 0.14 & 0.07 \\
\hline C.D. @ 5\% & NS & NS & NS & NS & NS & NS & NS & NS & NS & NS & NS & NS \\
\hline
\end{tabular}


Table.3 Effect of date of sowing and foliar application of nutrients on chlorophyll content and seed yield of soybean

\begin{tabular}{|c|c|c|c|c|c|c|c|c|c|}
\hline \multirow{2}{*}{$\begin{array}{l}\text { Treatments } \\
\text { Main plot (D) }\end{array}$} & \multicolumn{3}{|c|}{ Chlorophyll content } & \multicolumn{3}{|c|}{ Seed yield/Plot (Kg) } & \multicolumn{3}{|c|}{ Seed yield (q/ha) } \\
\hline & 2016 & 2017 & Pooled & 2016 & 2017 & Pooled & 2016 & 2017 & Pooled \\
\hline$D_{1}$ & 43.19 & 41.82 & 42.51 & 3.26 & 3.24 & 3.25 & 32.46 & 32.24 & 32.35 \\
\hline $\mathbf{D}_{2}$ & 40.80 & 38.65 & 39.73 & 3.13 & 3.11 & 3.12 & 31.13 & 30.96 & 31.05 \\
\hline $\mathbf{D}_{3}$ & 39.83 & 37.93 & 38.88 & 2.59 & 2.57 & 2.58 & 25.75 & 25.52 & 25.63 \\
\hline S. Em. \pm & 0.13 & 0.16 & 0.50 & 0.059 & 0.059 & 0.006 & 0.58 & 0.58 & 0.41 \\
\hline C.D. @ 5\% & 0.51 & 0.61 & 1.62 & 0.230 & 0.230 & 0.020 & 2.27 & 2.27 & 1.34 \\
\hline \multicolumn{10}{|l|}{ Sub Plot (T) } \\
\hline $\mathbf{T}_{1}$ & 36.85 & 34.93 & 35.89 & 2.73 & 2.70 & 2.72 & 27.13 & 26.86 & 27.00 \\
\hline$T_{2}$ & 39.47 & 37.70 & 38.58 & 2.90 & 2.88 & 2.89 & 28.86 & 28.69 & 28.77 \\
\hline$T_{3}$ & 40.89 & 39.05 & 39.97 & 2.99 & 2.97 & 2.98 & 29.72 & 29.52 & 29.62 \\
\hline$T_{4}$ & 41.81 & 40.25 & 41.03 & 3.04 & 3.02 & 3.03 & 30.28 & 30.05 & 30.17 \\
\hline$T_{5}$ & 38.39 & 36.55 & 37.47 & 2.81 & 2.79 & 2.80 & 27.93 & 27.73 & 27.83 \\
\hline$T_{6}$ & 44.26 & 42.41 & 43.33 & 3.16 & 3.14 & 3.15 & 31.41 & 31.21 & 31.31 \\
\hline $\mathbf{T}_{7}$ & 44.26 & 42.41 & 43.33 & 3.16 & 3.14 & 3.15 & 31.41 & 31.21 & 31.31 \\
\hline$T_{8}$ & 44.27 & 42.42 & 43.34 & 3.17 & 3.15 & 3.16 & 31.51 & 31.31 & 31.41 \\
\hline S. Em. \pm & 0.31 & 0.29 & 0.63 & 0.089 & 0.089 & 0.015 & 0.89 & 0.88 & 0.63 \\
\hline C.D. @ 5\% & NS & NS & NS & 0.254 & 0.253 & 0.042 & 2.53 & 2.52 & 1.76 \\
\hline \multicolumn{10}{|c|}{ Interactions (D x T) } \\
\hline $\mathbf{D}_{1} \mathbf{T}_{\mathrm{I}}$ & 38.70 & 36.98 & 37.84 & 3.02 & 3.01 & 3.02 & 30.05 & 29.95 & 30.00 \\
\hline$D_{1} \mathbf{T}_{2}$ & 41.41 & 40.35 & 40.88 & 3.19 & 3.18 & 3.19 & 31.75 & 31.64 & 31.70 \\
\hline$D_{1} T_{3}$ & 43.40 & 42.51 & 42.96 & 3.26 & 3.23 & 3.25 & 32.44 & 32.14 & 32.29 \\
\hline$D_{1} \mathbf{T}_{4}$ & 43.74 & 42.86 & 43.30 & 3.31 & 3.29 & 3.30 & 32.94 & 32.74 & 32.84 \\
\hline $\mathbf{D}_{1} \mathbf{T}_{5}$ & 40.62 & 39.21 & 39.92 & 3.11 & 3.09 & 3.10 & 30.95 & 30.75 & 30.85 \\
\hline $\mathbf{D}_{1} \mathbf{T}_{6}$ & 45.89 & 44.20 & 45.05 & 3.40 & 3.37 & 3.38 & 33.83 & 33.53 & 33.68 \\
\hline $\mathbf{D}_{1} \mathbf{T}_{7}$ & 45.89 & 44.20 & 45.05 & 3.40 & 3.37 & 3.38 & 33.83 & 33.53 & 33.68 \\
\hline$D_{1} T_{8}$ & 45.90 & 44.21 & 45.06 & 3.41 & 3.38 & 3.40 & 33.93 & 33.63 & 33.78 \\
\hline $\mathbf{D}_{2} \mathbf{T}_{1}$ & 36.46 & 34.61 & 35.54 & 2.87 & 2.84 & 2.86 & 28.56 & 28.25 & 28.41 \\
\hline $\mathbf{D}_{2} \mathbf{T}_{2}$ & 38.70 & 36.43 & 37.57 & 3.04 & 3.01 & 3.02 & 30.25 & 29.95 & 30.10 \\
\hline $\mathbf{D}_{2} \mathbf{T}_{3}$ & 39.98 & 37.61 & 38.80 & 3.12 & 3.11 & 3.11 & 31.05 & 30.95 & 31.00 \\
\hline $\mathbf{D}_{2} \mathbf{T}_{4}$ & 41.22 & 39.69 & 40.45 & 3.19 & 3.17 & 3.18 & 31.75 & 31.54 & 31.65 \\
\hline $\mathbf{D}_{2} \mathbf{T}_{5}$ & 37.68 & 34.82 & 36.25 & 2.96 & 2.94 & 2.95 & 29.45 & 29.25 & 29.35 \\
\hline $\mathbf{D}_{2} \mathbf{T}_{6}$ & 44.12 & 42.00 & 43.06 & 3.28 & 3.27 & 3.28 & 32.64 & 32.54 & 32.59 \\
\hline $\mathbf{D}_{2} \mathbf{T}_{7}$ & 44.12 & 42.00 & 43.06 & 3.28 & 3.27 & 3.28 & 32.64 & 32.54 & 32.59 \\
\hline $\mathbf{D}_{2} \mathbf{T}_{8}$ & 44.13 & 42.01 & 43.07 & 3.29 & 3.28 & 3.29 & 32.74 & 32.64 & 32.69 \\
\hline $\mathbf{D}_{3} \mathbf{T}_{1}$ & 35.38 & 33.21 & 34.30 & 2.29 & 2.25 & 2.27 & 22.78 & 22.39 & 22.59 \\
\hline $\mathbf{D}_{3} \mathbf{T}_{2}$ & 38.30 & 36.32 & 37.31 & 2.47 & 2.46 & 2.47 & 24.58 & 24.48 & 24.53 \\
\hline $\mathbf{D}_{3} \mathbf{T}_{3}$ & 39.28 & 37.02 & 38.15 & 2.58 & 2.56 & 2.57 & 25.67 & 25.47 & 25.57 \\
\hline $\mathbf{D}_{3} \mathbf{T}_{4}$ & 40.46 & 38.21 & 39.33 & 2.63 & 2.60 & 2.62 & 26.17 & 25.87 & 26.02 \\
\hline $\mathbf{D}_{3} \mathbf{T}_{5}$ & 36.86 & 35.61 & 36.23 & 2.35 & 2.33 & 2.34 & 23.39 & 23.19 & 23.29 \\
\hline$D_{3} T_{6}$ & 42.77 & 41.01 & 41.89 & 2.79 & 2.77 & 2.78 & 27.76 & 27.56 & 27.66 \\
\hline $\mathbf{D}_{3} \mathbf{T}_{7}$ & 42.77 & 41.01 & 41.89 & 2.79 & 2.77 & 2.78 & 27.76 & 27.56 & 27.66 \\
\hline $\mathbf{D}_{3} \mathbf{T}_{8}$ & 42.78 & 41.02 & 41.90 & 2.80 & 2.78 & 2.79 & 27.86 & 27.66 & 27.76 \\
\hline S. Em. \pm & 0.94 & 0.86 & 1.10 & 0.15 & 0.15 & 0.04 & 1.54 & 1.53 & 1.09 \\
\hline C.D. @ $5 \%$ & NS & NS & NS & NS & NS & NS & NS & NS & NS \\
\hline
\end{tabular}


Fig.1 Fortnight meteorological observations during crop growth period

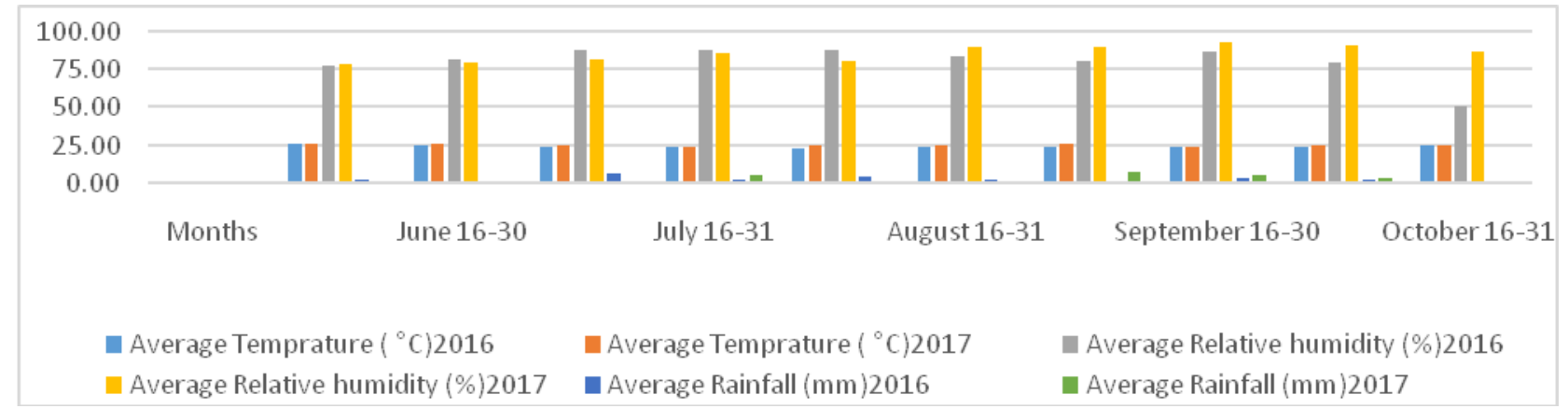

Fig.2 Effect of date of sowing and foliar application of nutrients on reproductive stages of soybean

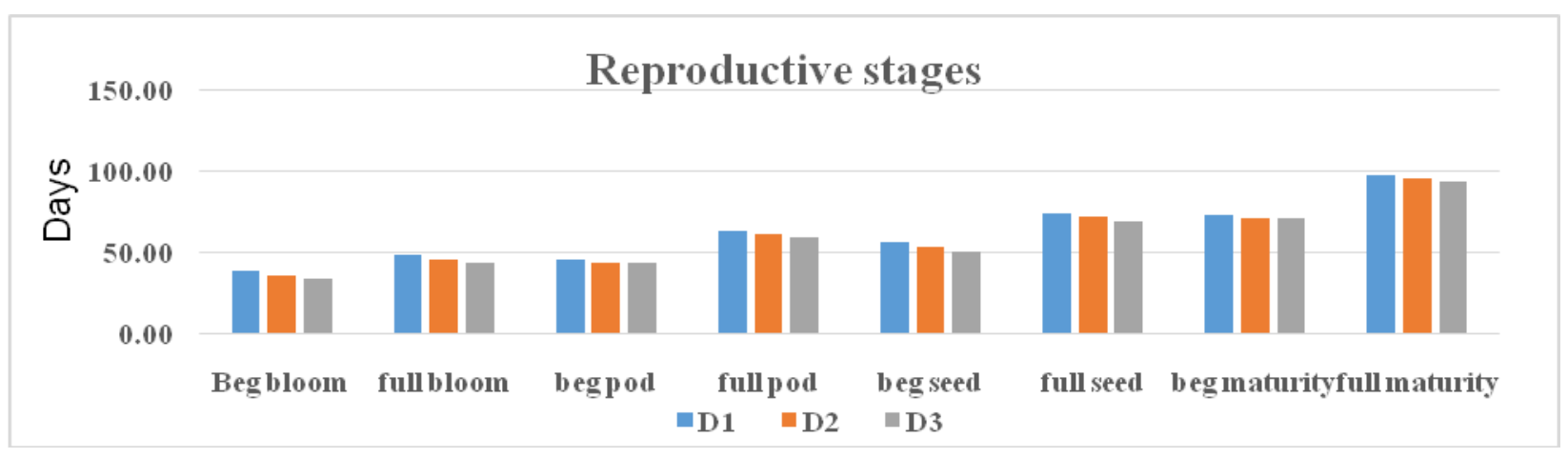


During crop growth period, which accelerated development towards reproductive stage and hence less time was available for the plant for vegetative growth and leading to early maturity. These results are in accordance with the findings of Khan et al., (2003) and Islami and Sugito (2012) who explained that the number of days to maturity of soybean declined with each successive sowing date due to high temperatures during vegetative development which might have shortened intervals between vegetative and reproductive growth stages. Muldon (2002) stated that the late planting had a shorter period for the production of pods and also a slightly low rate of pod production coupled with reduced growth due to exposure of plant to warmer weather and longer photoperiod. Hence, late planting attained maturity earlier than normal date of sowing. A steady decrease in number of days to maturity took place when planting was delayed. Minimum days to maturity with delay in planting may be due to quick changes in photoperiod and temperature as in case of plant height (Asim et al., 2014).

In general, seed yield per plot recorded decreasing trend as date of sowing delayed. Among the date of sowings, significantly highest seed yield per plot (3.26, 3.24 and $3.25 \mathrm{~kg}$ ) was recorded in $\mathrm{D}_{1}$ (First fortnight of June) followed by $\mathrm{D}_{2}(3.13,3.11$ and $3.12 \mathrm{~kg})$ and significantly lower yield $(2.59,2.57$ and $2.58 \mathrm{~kg}$ ) was recorded in $\mathrm{D}_{3}$ (First fortnight of July) during 2016, 2017 and pooled data respectively.

Significantly highest seed yield per hectare (32.46, 32.24 and 32.35 q) was recorded in $\mathrm{D}_{1}$ (First fortnight of June) followed by $\mathrm{D}_{2}$ $(31.13,30.96$ and 31.05 q). However significantly lower yield $(25.75,25.52$ and $25.63 \mathrm{q}$ ) was recorded in $\mathrm{D}_{3}$ (First fortnight of July) during 2016, 2017 and pooled data respectively.
This might be due to a shortened vegetative growth period. These results are in accordance with the findings of Khan et al., (2004) who reported that early sowing of soybean produced significantly higher seed yield than delayed sowing. They further mentioned that higher yields of earlier sowings were ascribed to photoperiod response which lengthened both vegetative and reproductive stages, enabling crop to produce more dry matter which was efficiently utilized by prolonged pod filling period after flowering resulting in a higher seed yield. Sadegi and Niyaki (2013) observed a steady decrease in soybean seed yield when sowing was delayed due to lack of sufficient vegetative growth, lower number of pods per plant and reduced seed weight. Reduction in seed yield with delayed sowing was also confirmed and reported by Karaaslan et al., (2012). Among the foliar application of nutrients, $\mathrm{T}_{8}\left(\mathrm{KNO}_{3} @ 0.5 \%+\mathrm{KH}_{2} \mathrm{PO}_{4} @ 0.5\right.$ $\%+$ Boron $0.50 \%$ ) noticed significantly highest seed yield per plot $(3.17,3.15$ and $3.16 \mathrm{~kg})$ which is on par $(3.16,3.14$ and 3.15 kg) with $\mathrm{T}_{6}(19: 19: 19$ NPK @ $3 \%+$ Boron @ $0.50 \%)$ and $\mathrm{T}_{7}\left(\mathrm{KNO}_{3} @ 1 \%+\mathrm{KH}_{2} \mathrm{PO}_{4} @\right.$ $0.5 \%)$ and lowest seed yield per plot (2.73, 2.70 and $2.71 \mathrm{~kg}$ ) was recorded in control during 2016, 2017 and pooled data respectively.

Among the foliar application of nutrients, $\mathrm{T}_{8}$ $\left(\mathrm{KNO}_{3} @ 0.5 \%+\mathrm{KH}_{2} \mathrm{PO}_{4} @ 0.5 \%+\right.$ Boron $0.50 \%$ ) noticed significantly highest (31.51, 31.31 and 31.41 q) seed yield per hectare which is on par $(31.41,31.21$ and 31.31 q) with $\mathrm{T}_{6}(19: 19: 19 \mathrm{NPK} @ 3 \%+$ Boron @ $0.50 \%)$ and $\mathrm{T}_{7}\left(\mathrm{KNO}_{3} @ 1 \%+\mathrm{KH}_{2} \mathrm{PO}_{4} @\right.$ $0.5 \%$ )and lowest $(27.13,26.86$ and 27.00 q) seed yield per hectare was recorded in control during 2016, 2017 and pooled data respectively. higher seed yield recorded in $\mathrm{T}_{8}$ might be due to the significant effect of nutrient sprays enhancing number of pods per plant and the role of boron in enhancing dry 
matter and efficiency of translocation of assimilates to developing sink leading to increased pods and higher seed yield (Pradeep and Elamathi, 2007). Potassium might have improved pod filling and phytomass production due to beneficial functions of nitrogen, the prevalence of $\mathrm{K}^{+}$in $\mathrm{KNO}_{3}$, might have improved grain filling and phytomass production, increasing photosynthetic activity and effective translocation of assimilates to reproductive parts resulting in higher yield (Vaseghi et al., 2013 in soybean) whereas, $\mathrm{T}_{6}(19: 19: 19$ NPK @ 3\%+Boron@ 0.50\%) also recorded on par values. This may be attributed to fulfillment of the demand of the crop by higher assimilation and translocation of photosynthates from leaves) to pods. Through supply of required nutrients by foliar spray of 19:19:19 NPK supply of balanced NPK with micronutrient enhance photosynthesis, metabolic activity, formation of organic constituents and their translocation from source to sink results in highest grain yield. Similar results were also reported by Kalpana (2001) and Dixit and Elamathi (2007).

Thus from the experiment it could be concluded that with delayed sowing, crop growth and seed yield of soybean were adversely affected. Small fluctuations in the weather (temperature) showed higher variations in plant growth and development, which finally influenced on the crop growth and yield of soybean. Considering the changes in plant growth and yield, first fortnight of June sowing sprayed with $\mathrm{KNO}_{3}$ (a) $0.5 \%+\mathrm{KH}_{2} \mathrm{PO}_{4}$ @ $0.5 \%+$ Boron $0.50 \%$ and also 19:19:19@3\%+Boron@ @ $0.50 \%$ maintained better crop growth, chlorophyll content and seed yield of soybean.

\section{References}

Alexandrov, V. A. and Hoogenboom, G. 2001. Climate variation and crop production in Georgia, USA during the twentieth century. Climate Research. 17(1): 33-43.

Ali, E. A. and Adel, M. M., 2013. Effect of foliar spray by different salicylic acid and zinc concentrations on seed yield and yield components of mungbean in sandy soil. Asian Journal Crop Sciences. 5 (1): 33-40.

Anonymous. 2017. USDA, Foreign Agricultural Services, Washington, DC.

Asim, M. S., Khalil, K and Khan, M. S. 2014. Performance of land races and improved varieties of soybean planted on different planting dates in clay loam soil of Peshawar. World Applied Sciences Journal. 30 (3): 279-285.

Banterng, P., Patanothai, A., Pannangpetch, K., Jogloy, S. and Hoogenboom, G. 2003. Seasonal variation in the dynamic growth and development traits of peanut lines. Journal of Agricultural Science. 141: 51-62.

Bastidas, A. M., Setryono, T. D., Dobermann, A., Cassman, K. G., Elmore, R. W., Graef, G. L. and Specht, J. E. 2008. Soybean sowing date: The vegetative, reproductive and agronomic impacts. Crop Science. 48: 727-740.

Beg, M. Z., Ahmad, S. and Srivastava, D. K. 2013. Foliar application of potassium on urd bean. Indian Journal Science. 2 (2): 67-70.

Dixit, P. M. and Elamathi, S. 2007. Effect of foliar application of DAP, micronutrients and NAA on growth and yield of green gram (Vigna radiata $\mathrm{L}$.). Legume Research. 30(4):305-307.

Frimpong, A. 2004. Characterization of groundnut (Arachis hypogaea L.) in northern Ghana. Pakistan Journal of Biological Sciences. 7(5): 838-842.

Gowthami, P. G., Rama, R, and Lal. A. M. 2018. Effect of foliar application of potassium, boron and zinc on quality and seed yield in soybean. International 
Journal of Chemical Studies. 6 (1): 142144

Gupta, S. C., Sangeev, K. and Khandwe. 2011. Effect of biofertilizer and foliar spray of urea on symbiotic traits, nitrogen uptake and productivity of chickpea. Food legume. 24(2): 155157.

Islami, T. and Sugito, Y. 2012. The effect of planting date and harvesting time on the yield and seed quality of rainy season soybean [Glycine $\max$ (L.) Merrill]. Journal of Agricultural Food Technology. 2(4): 73-78.

Jayabal, A., Revathy, M. and Saxena, M. G. 1999. Effect of foliar nutrition on nutrient uptake pattern in soybean. Andhra Agriculture Journal. 46: 243244.

Kalpana, R. 2001. Effect of irrigation layouts and foliar spraying of nutrients and growth hormone on soybean [Glycine $\max ($ L.) Merill]. Ph. D. (Ag.) Thesis, Agril. Univ. Tamil Nadu Coimbatore, (India).

Karaaslan, D., Hakan, M., Ekinci, R. and Boydak, E. 2012. The impact of different seeding dates on seed yield of soybean. The Journal of Animal and Plant Science. 22(1): 175-182.

Khan, A. Z., Shah, P., Khalil, S. K and Taj, F. H. 2003. Influence of planting date and plant density on morphological traits of determinate and indeterminate soybean cultivars under temperate environment. Pakistan Journal of Agronomy. 2(3): 146-152.

Khan, A. Z., Shah, P., Khalil, S. K. and Ahmed, B. 2004. Yield of soybean cultivars as affected by planting date under Peshawar valley conditions. The Nucleus. 41: 93-95.

Kumar, A., Tripathi, M. K. and Pal, V. 2015. Effect of sowing time on growth, phenology and yield attribute of summer groundnut (Arachis hypogaea
L.) in Allahabad. International Journal of Current and applied microbiological Sciences. 6(4): 2357-2365.

Mahmoud, M., Abdalla., Fouad El-Sayed., Abou El-Nour., El-Zanaty Abdel Mottaleb Aly., El-Saady and Abdel K. M. 2006. Boron/Nitrogen interaction effect on growth and yield of fababean plants grown under sandy soil conditions. International Journal of Agricultural Research. 1(4): 322-330.

Mohankumar, B. N., Basavegowda., Vyakaranahal, B. S., Deshpande, V. K. and Kenchanagoudar, P. V. 2011. Influence of sowing dates on production of seed yield in niger (Guizotia abyssinica Cass.). Karnataka Journal of Agricultural Sciences. 24(3): 289 - 293.

Muldon, D. K. 2002. The effect of time and sowing and row spacing on the maturity and yield of three groundnut cultivars under irrigation. Australian Journal Agricultural Research. 36: 615-621.

Patel, P. K. and Hemanthranjan, A. 2013. Differential sensitivity of chickpea genotypes to salicylic acid and drought stress during pre anthesis: Effects on total chlorophyll, phenolics, seed protein and protein profiling. The Bioscan. 8(2): 569-574

Prabhavathi, K., Bidari, B. I., Shashidhara, G. B., Mathad, J. C. 2009. Effect of levels and sources of potassium on yield and nutrient uptake by mungbean in a vertisol. An Asian Journal of Soil Science. 4: 49-51.

Pradeep, M. D. and Elamathi, S. 2007. Effect of foliar application of DAP, micronutrients and NAA on growth and yield of greengram (Vigna radiataL.). Legume Research. 30(4): 305-307.

Sadeghi, S. M. and Niyaki, S. N. 2013. Effects of Planting date and cultivar on the yield and yield components of soybean in north of Iran. Journal of Agricultural Biological Science. 8(1): 
81-85.

Sarkar, R. K. and Pal, P. K. 2006. Effect of pre-sowing seed treatment and foliar spray of nitrate salts on growth and yield of green gram (Vigna radiataL.). Indian Journal of Agricultural Science. 76(1): 62-65.

Singla, S., Grover, K., Angadi, S. V., Begna, S. H., Schutte, B. and Leeuwen, D. V. 2016. Growth and yield of guar (cyamopsis tetragonoloba L.) genotypes under different planting dates in the semi-arid southern high plains. American Journal of Plant Science. 7: 1246-1258.

Thurzo, S., Szabo, Z., Nyeki, J., Silva, A. P., Nagy, P.T. and Goncalves, B. 2010. Effect of boron and calcium sprays on photosynthetic pigments, total phenols and flavonoid content of sweet cherry (Prunu savium L.). Acta Hortic. 868, 457-461.
Vaseghi, S., Valinejad, M. and Mehran Afzali. 2013. Boron fertilizer effects on soybean yield, leaf and boron concentration in seed. World of Science Journal. 1 (10): 178-188.

Vibhute, C. P. 1998. A process for manufacturing complex solid and liquid completely water soluble fertilizer. Fertilizer News. 43(8): 63-69.

Zayed, B. A., Salem, A. and Sharkawy, H. M. 2011. Effect of different micronutrient treatments on rice (Oryza sativa L.) growth and yield under saline soil conditions. World Journal of Agricultural Science. 7 (2): 179-184.

Zayed, B. A., Salem, A. and Sharkawy, H. M. 2011. Effect of different micronutrient treatments on rice (Oryza sativa L.) growth and yield under saline soil conditions. World Journal of Agricultural Science. 7 (2): 179-184.

\section{How to cite this article:}

Sumalatha, G.M. and Uppar, D.S. 2019. Influence of Date of Sowing and Foliar Application of Nutrients on Crop Growth and Seed Yield of Soybean. Int.J.Curr.Microbiol.App.Sci. 8(01): 2020-2032. doi: https://doi.org/10.20546/ijcmas.2019.801.212 